\title{
lodine-125 induces apoptosis via regulating p53, microvessel density, and vascular endothelial growth factor in colorectal cancer
}

Zhenhuan Ma ${ }^{1,2}$, Yong Yang ${ }^{1,2^{*}}$, Guokai Yang ${ }^{1,2}$, Jia Wan ${ }^{1,2}$, Guojian $\mathrm{Li}^{1,2}$, Ping Lư ${ }^{1,2}$ and Lingjuan Du ${ }^{1,2}$

\begin{abstract}
Background: lodine interstitial brachytherapy has been widely reported for treating colorectal cancer (CRC). However, the inhibitory molecular mechanism of iodine-125 (I-125) on CRC has not been reported.

Methods: To illustrate the inhibitory mechanism of iodine-125 (I-125) on CRC, we established the animal models of CRC via the injection of HCT-8 cells into nude mice. Subsequently, the I-125 granules were implanted into the tumor of the animal model at different dosages. Proliferating cell nuclear antigen and terminal transferase dUTP nick end labeling were used to detect the apoptosis of the tumor cells. Immunohistochemistry SP staining was used to measure the expression of p53 protein. The protein levels were examined with western blot and ELISA. Meanwhile, microvessel density (MVD) was counted by endothelial cells immunostained by anti-CD34 antibody.

Results: The results showed that I-125 protests against CRC via increasing the protein level of p53 and decreasing the level of vascular endothelial growth factor (VEGF), leading to the decrease of MVD in CRC $(P<0.0001)$. An effective inhibition dosage of $\mathrm{I}-125$ ranged from 0.4 to $0.8 \mathrm{mCi}$.
\end{abstract}

Conclusions: The inhibitory mechanisms of iodine on CRC acted through an increase in the level of p53 and a decrease in the level of VEGF, resulting in a decrease of MVD.

Keywords: Colorectal cancer, HCT-8 tumor model, I-125 interstitial brachytherapy, Microvessel density, p53 protein, Vascular endothelial growth factor

\section{Background}

According to a previous report [1], colorectal cancer $(\mathrm{CRC})$ is the third most common cancer in men and the second in women worldwide, with most cases occurring in developed regions. Existing treatments are ineffective in the cure of CRC [2]. Further, the cancer's size and/or position may make surgery difficult and thus patients survive for only a short time after surgery [3]. Additionally, gastrointestinal stromal tumors (GISTs), a subset of soft tissue sarcomas, have proven to be insensitive to chemotherapy and radiotherapy [4].

Radioactive iodine-125 (I-125) seed implantation can improve the target volume dose with a high level of radioactive iodine. The tumor, which is refractory and

\footnotetext{
* Correspondence: yyyunnan@163.com

'Department of General Surgery, the Second People's Hospital of Yunnan, Kunming 650021, China

${ }^{2}$ Center of Vascular Surgery, The Fourth Affiliated Hospital, Kunming Medical College, Kunming 650021, China
}

\section{() Bïomed Central}

insensitive to chemotherapy and radiotherapy, can be effectively controlled via iodine treatment [5]. Furthermore, the preservation of urinary, sexual, and rectal quality of life is excellent at long-term follow-up for the patients implanted with I-125 [6]. Iodine interstitial brachytherapy has been widely reported for treating CRC. Segmental intraluminal instillation of iodine was advocated to prevent anastomotic recurrence after colonic resection for CRC [7]. Most patients with recurrent or metastatic CRC underwent radio-immune-guided surgery [8]. I-125 has also been widely applied to treat other cancers. For instance, I-125 brachytherapy implantation is a safe and effective treatment strategy for patients with both lower urinary tract symptoms and localized prostate cancer [9]. Combined techniques with I-125 implant show better anti-tumor effects. Further, the addition of external beam radiotherapy can confer a significant biochemical control for prostate 
cancer when it is added to I-125 brachytherapy [10]. The patients with IS-IV (interval survival for stage IV pancreatic cancer), received radical treatment, are significantly longer than those who received palliative treatment. Multiple treatments play an important role in improving the IS-IV of patients who received radical treatment [11].

The inhibitory molecular mechanisms of iodine on some cancers have been reported [12-14]. However, the inhibitory molecular mechanism of I-125 on CRC is still widely unknown. Understanding the molecular mechanism will be beneficial to make full use of the I- 125 brachytherapy implant techniques effectively and safely. CRC models with nude mice are readily available $[15,16]$, allowing for the exploration of the inhibitory molecular mechanisms of I-125 on CRC. We established a CRC animal model using nude mice, followed by the implant of the I-125 granules at different dosages. The inhibitory molecular mechanisms were explored and are described herein.

\section{Methods}

\section{Cell culture}

As previously described [17], HCT-8 cells were maintained under serum-free conditions using McCoy's 5A medium supplemented with $4 \mu \mathrm{g} / \mathrm{mL}$ of transferrin, $5 \mu \mathrm{g} / \mathrm{mL}$ of insulin, and $10 \mathrm{ng} / \mathrm{mL}$ of vascular endothelial growth factor (VEGF) in a $5 \% \mathrm{CO}_{2}$ at $37^{\circ} \mathrm{C}$ and $100 \%$ humidity, and passaged every 2 or 3 days.

\section{Orthotopic implantation}

All the protocols were approved by the animal care and ethics committee of the Second People's Hospital of Yunnan (Kunming, China). Informed consent was obtained from each patient before the study. BALB/c nude male mice were raised in a HEPA-filtered environment. HCT-8 labeled cells were subcutaneously injected into the mice. At $1 \mathrm{~cm}^{3}$, the xenograft was excised and minced for implantation into other 4- to 6-week-old BALB/c nude mice. One $1 \mathrm{~mm}^{3}$ piece per mouse was subcutaneously implanted to the axillary region of 50 other $\mathrm{BALB} / \mathrm{c}$ nude male mice, as previously described [18].

\section{I-125 brachytherapy seed implant}

Five days after the tumors were implanted, an I-125 seed or an inactive sham seed was inserted into the tumor areas of the mice model. Every 10 mice received experimental seeds with the radio dosage of $0.2,0.4$, and 0.8 $\mathrm{mCi}$. Ten control mice received the sham seeds or did not receive the implant. Every 5 days, the tumor volume was calculated using the modified ellipsoid formula $1 / 2\left(\right.$ Length $\left.\times \mathrm{Width}^{2}\right)$. All mice were sacrificed after 15 days.

\section{The determination of $\mathrm{p} 53$}

Immunohistochemical SP staining was used to determine the protein levels of p53 according to a previous report [19]. Briefly, 5- $\mu \mathrm{m}$ formalin-fixed paraffin-embedded sections from the tumors were boiled for $5 \mathrm{~min}$ in the presence of lead thiocyanate solution. Sections were incubated at room temperature for $30 \mathrm{~min}$ with a 1:1,000 dilution of the polyclonal antibody, CM-1 (Covance, Inc., Beijing, China) against p53 protein after blocking endogenous peroxidase activity with goat serum. Immunohistochemical staining was performed using the streptavidin-biotin complex procedure according to the manufacturer's direction (Advanced Technology \& Industrial Co., Ltd., Hong Kong). As a control, the same procedure was carried out except that the primary antibody was replaced by PBS. The neoplastic areas were examined for immunohistochemical staining by one investigator, blinded to the p53 mutation status. Only the nuclear immunostaining was considered as positive for $\mathrm{p} 53$ protein accumulation. The level of protein accumulation was scored as 0 (no detectable immunostaining), 1 (few nuclei), 2 (up to $10 \%$ nuclei), 3 (10 to $50 \%$ nuclei), and 4 (>50\% nuclei). The numerical scoring was confirmed by a second independent examination, blinded to the initial score.

\section{Proliferating cell nuclear antigen (PCNA) and terminal transferase dUTP nick end labeling (TUNEL) assay for apoptosis}

PCNA was examined to investigate cell proliferation, which can reflect the degree of the cellular apoptosis. All cells were fixed in PBS formalin, embedded in paraffin and stained. PCNA was performed using a labeled streptavidin-biotin. Anti-PCNA monoclonal antibody (DAKO, Carpenteria, CA, USA) reacted exclusively with nuclei.

TUNEL was also performed to examine the apoptosis according to a previous report [20]. All cells were suspended in PBS buffer by gently vortexing the vials and aliquoted to approximately $1 \times 10^{6}$ cells $/ \mathrm{mL}$ per test. The cells were collected via centrifuge for $5 \mathrm{~min}(300 \mathrm{~g})$ and resuspended in $1 \mathrm{~mL}$ of the wash buffer in each tube. After washing three times, $50 \mu \mathrm{L}$ of the TdT enzyme mixture were added to the sample and incubated for $60 \mathrm{~min}$ at $37^{\circ} \mathrm{C}$ in a water bath. Subsequently, the cells were washed three times and resuspended in $0.1 \mathrm{~mL}$ of the antibody labeling mix. The tubes were incubated in the dark for $30 \mathrm{~min}$ at room temperature. The cells were washed three times and suspended in $0.9 \mathrm{~mL}$ PBS. One hundred $\mu \mathrm{L}$ propidium iodide/RNase were added to each tube. After 3 hours of staining, the samples were analyzed by flow cytometry. 


\section{Detection for the expression of vascular endothelial growth factor (VEGF) and quantitation of microvessel density (MVD)}

The expression level of VEGF was determined according to Takahashi standard [21]. Immunohistochemical analyses, using the antibodies against VEGF and PCNA, were performed in 50 human colon carcinomas. Vessels were quantitated by light microscopy and the intensity of staining for VEGF was assessed on a scale of 0 to $3+$. Proliferation was determined by counting the number of PCNA-positive cells per 500 tumor cells. The high expression of VEGF was correlated with the extent of neovascularization and the degree of cellular proliferation.

MVD, a measure of angiogenesis in tumors, has been shown to be a prognostic indicator that correlates with an increased risk of metastasis in various cancers [22]. MVD was measured according to a previous report [23].

\section{Western blotting analysis}

After I-125 treatments with different dosages, cells were washed in Dulbecco's phosphate-buffered saline (DPBS) (Life Technologies, Grand Island, USA) and incubated in cysteine-free/methionine-free DMEM (Life Technologies, Inc.) for $30 \mathrm{~min}$. One $6-\mathrm{cm}$ plate containing $1 \times 10^{6}$ cells was used for per sample. Cell lysates were prepared as previously described [24]. Total protein in lysates was quantified using Bradford reagent (Bio-Rad Laboratories, Inc., Richmond, CA, USA). All proteins were separated on $10 \%$ SDS-PAGE. Western blot analysis was conducted with the monoclonal antibody against p53 (clone BP53-12 at a 1:50 dilution, Novocastra, Newcastle upon Tyne, UK) and polyclonal antibody against VEGF (clone A-20 at a 1:300 dilution, Santa Cruz Biotechnology, Santa Cruz, CA, USA). $\beta$-actin (Sigma-Aldrich, St. Louis, MO, USA) was used as a loading control in the western blot.

\section{ELISA}

The concentration of p53 in the treated and untreated tissues was determined using p53 Abs ELISA kit [25] (Medical \& Biological Laboratories Co. Ltd., Nagoya, Japan). The concentration of VEGF in the treated and untreated tissues was determined using an ELISA kit with the antibodies which recognize VEGF165 [26] (R\&D Systems Inc., Minneapolis, USA). Glyceraldehyde-3-phosphate dehydrogenase hybridization was used as a loading control.

\section{Statistical analysis}

The statistic differences between two means were compared by one-way analysis of variance (ANOVA). Fisher's least significant difference test was used as post hoc tests of significant differences between two parameters. Data was analyzed using StatView 5.0 software (Abacus systems, Berkley, CA, USA) with a $P$ value of $<0.05$ accepted as significant.

\section{Results}

The effects of I-125 implant on tumor volume

Before the I-125 seed implant, the tumor volumes were almost the same. After the seed implant, the tumor volume in the $0.8 \mathrm{mCi}$ group was reduced by up to $40 \%$ compared with those from the controls with $0 \mathrm{mCi}$ (Figure 1); the difference was significant $(P<0.001)$. The effective inhibition dosage of I-125 ranged from 0.4 to $0.8 \mathrm{mCi}$ (Figure 1).

\section{Inhibitory rate of different dosages}

The weight of the different tumors was $5.26 \pm 0.31$, $5.27 \pm 0.25,4.13 \pm 0.13,3.47 \pm 0.17$, and $2.83 \pm 0.16 \mathrm{~g}$ in blank, 0, 0.2, 0.4, and $0.8 \mathrm{mCi}$ groups, respectively, giving a respective growth inhibition of $0,21.5 \%, 34.0 \%$, and $46.2 \%$. Thus, the $0.8 \mathrm{mCi} \mathrm{I-125}$ dosage showed effective inhibitory results for CRC.

\section{The assay for apoptosis}

The apoptosis was visualized in the tumors treated with I-125 under an oil microscope. According to a previous report, brown colored positive apoptotic cells were observed and normal cells were in a blue color with the TUNEL method [27]. Figure 2A shows that the nuclei were colored blue in the normal cancer cell. Five days after the I-125 seed implantation, the nuclei were stained a brown color with decreased expression of PCNA in apoptosis cells while the nuclei were of a normal color in the $0 \mathrm{mCi}$ group (Figure 2B1 and B2). Fifteen days after I-125 seed implantation, the nuclei disappeared because of the emerging destructive stage of apoptosis, while a few cells showed apoptosis in the $0 \mathrm{mCi}$ group (Figure 2C1 and C2). The TUNEL assay showed normal colon cells with a blue color while the germination of cells was found in the $0.8 \mathrm{mCi}$ group (Figure 2D1 and D2).

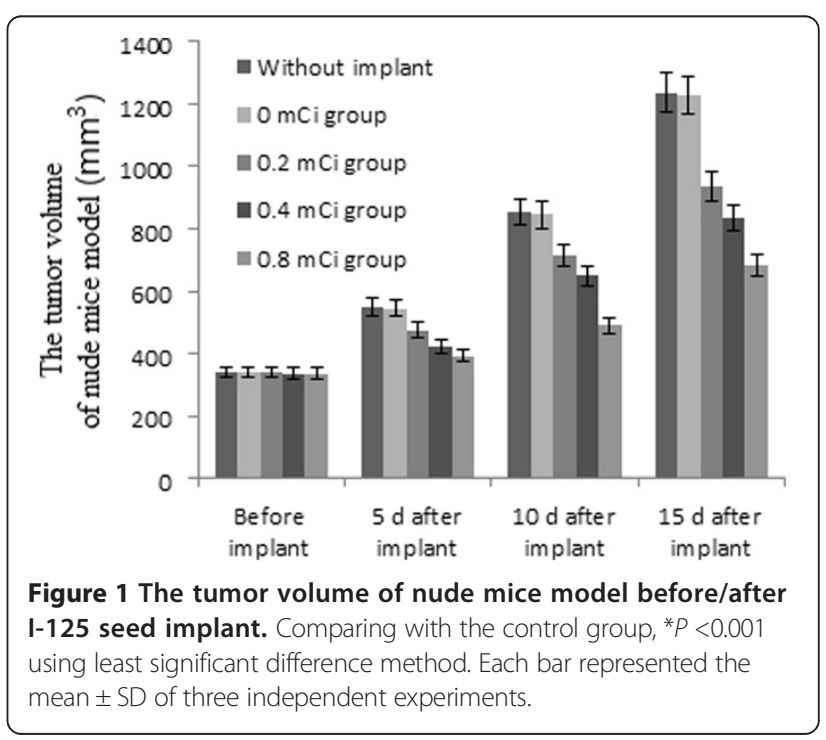




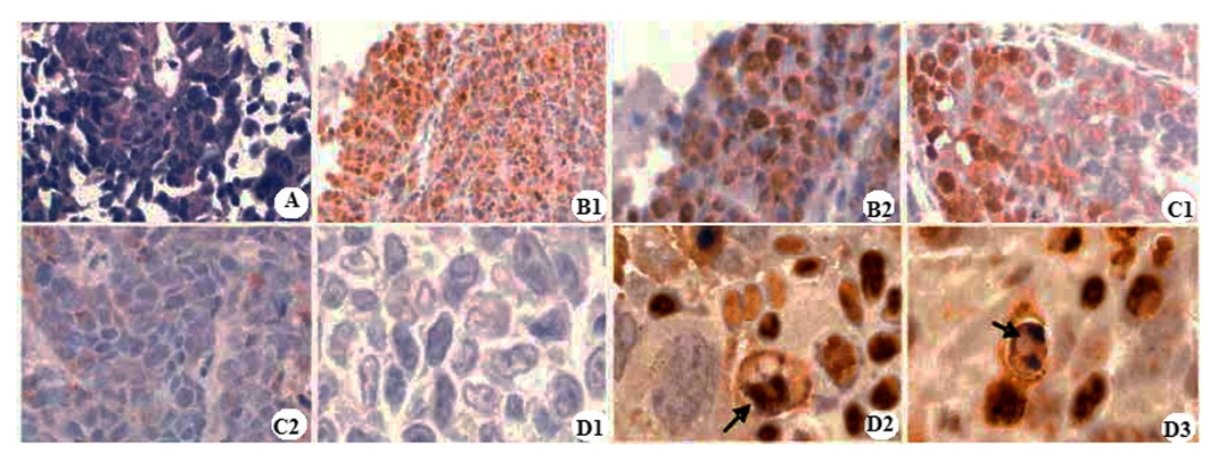

Figure 2 HCT-8 cell transplanted tumor $(\mathrm{HE} \times \mathbf{4 0 0})$. (A) Strong positive expression of PCNA protein on different phases after $1-125$ seed implantation; (B1) HCT-8 cell transplanted tumor before day 5 in the 0 mCi group (SP $\times 200)$; (B2) Day 5 in the 0.8 mCi group (SP $\times 400)$; (C1) Day 15 in the 0 mCi group $(\mathrm{SP} \times 400)$; (C2) Day 15 in the $0.8 \mathrm{mCi}$ group (SP $\times$ 400); (D1) 0 mCi group, a few apoptosis cells were seen, nuclei were stained blue and small nucleoli were seen; (D2) 0.8 mCi group, characteristic findings of cell apoptosis, germination was observed on day 10; (D3) 0.8 mCi group, vacuolization in the cytoplasm occurred in the apoptotic cell on day 15.

Vacuolization in the cytoplasm occurred in the apoptosis cell on day 15 of I-125 implantation (Figure 2D3).

\section{The association between MVD and VEGF}

The MVD for the five groups was $50.19 \pm 21.38,51.30 \pm$ $20.26,41.67 \pm 17.56,32.50 \pm 10.95$, and $22.62 \pm 7.14$, respectively. The expression of VEGF and MVD was closely related with the development of CRC. The results suggested that high protein level of VEGF caused high levels of MVD, which would increase the risk of colon cancer.

\section{The association between weights and MVD-VEGF}

We guessed that the weight of model mice might be affected by the levels of MVD and VEGF. Thus, the association between the weight and levels of MVD-VEGF was investigated here. The Spearman's rank correlation coefficient for the association between the weigh and the levels of MCD or VEGF in the tumors was 0.85 and 0.72 , respectively. Both $P$ values were less than 0.01 . The results suggested that the weight was strongly related with the levels of MVD or VEGF.

\section{The relative protein levels of $p 53$ and VEGF}

Compared with the control group, the expression level of p53 was up-regulated when it was treated by I-125 seeds from low- to high-dosage (Figure 3), suggesting that I-125 can increase the expression level of p53. p53 is an important cancer repressor [28], and thus the mechanism of iodine inhibition of CRC growth acts through activation of the levels of p53. Inversely, comparing the control group, the expression of VEGF was down-regulated when it was treated by I-125 from lowto high-dosage (Figure 3), suggesting that I-125 can reduce the expression of VEGF. Anti-VEGF has been studies in clinical trials for cancer therapy [29]; thus, iodine treatment is a better method for inhibiting the growth of CRC via the activation of anti-VEGF.

\section{The concentration of $\mathrm{p} 53$ and VEGF}

Compared with the control group, the concentration of p53 reached the highest level when the rats were treated with I-125 at the highest dosage (Figure 4), suggesting that I-125 can increase the concentration of p53. Just as analyzed by western blotting, p53 was an important

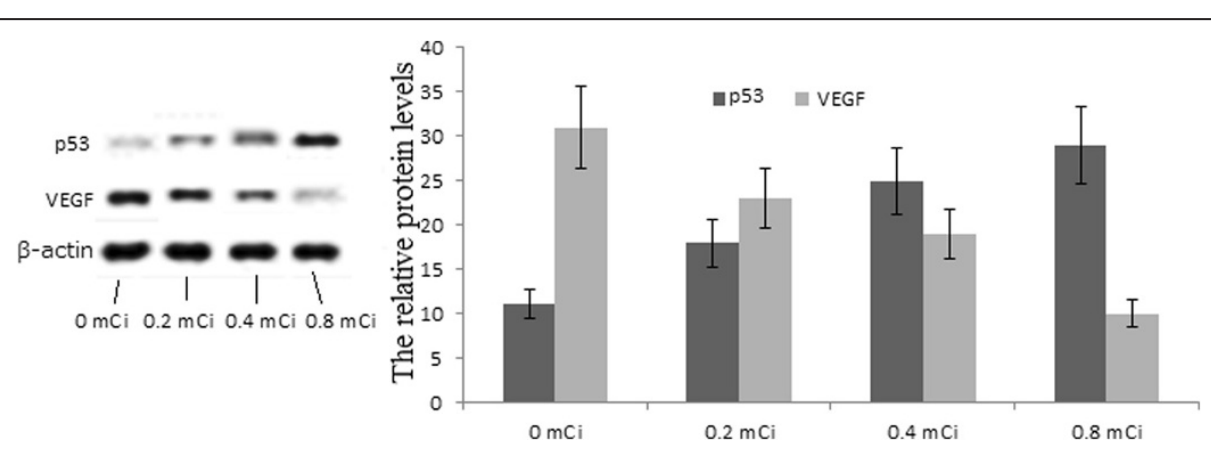

Figure 3 Western blotting analyses for the relative protein levels of $\mathrm{p} 53$ and VEGF in $0,0.2,0.4$, and $0.8 \mathrm{mCi}$ I-125-treated groups. $\beta$-actin was used as a loading control. Each bar represented the mean \pm SD of three independent experiments. 


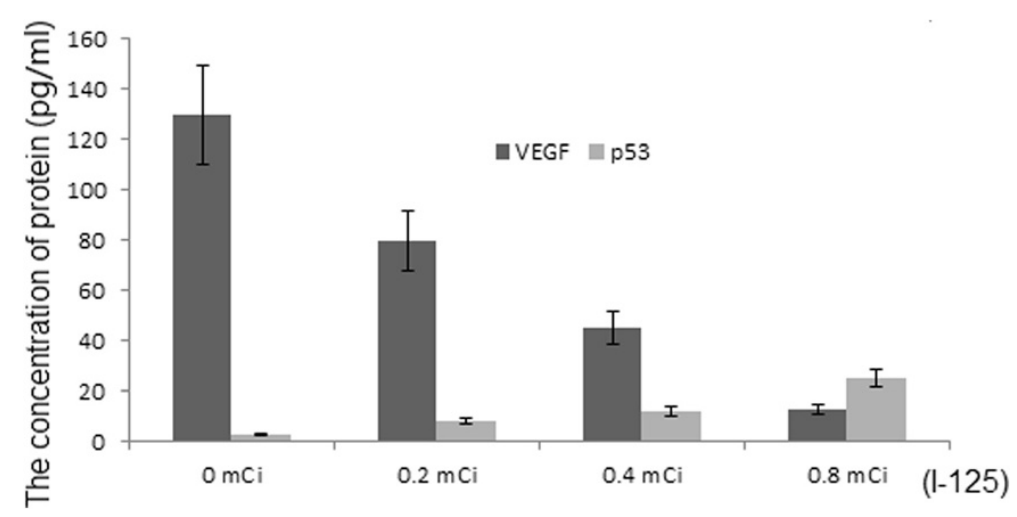

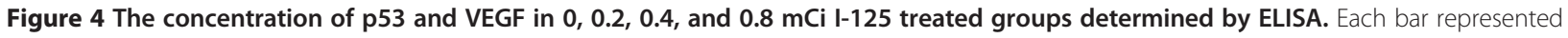
the mean \pm SD of three independent experiments.

cancer repressor, and the mechanism for iodine inhibiting the growth of CRC was to increase the level of p53. Inversely, compared with the control group, the concentration of VEGF was reduced to the lowest level when it was treated by I-125 at the highest dosage (Figure 4), suggesting that I-125 can reduce the concentration of VEGF.

\section{Discussion}

Cancer is a leading cause of death in the world and I-125 radiation therapy has proved effective in the treatment of various carcinomas [30-34]. The theoretical benefit of seed permanent implantation as a salvage treatment is to enhance disease control in the region of recurrence and to minimize the injury to the surrounding tissues [35,36]. However, the molecular mechanisms for I-125 inhibiting CRC are widely unknown. We were therefore interested to explore said mechanisms. Herein, we gained significant results in using I-125 seed implantation to treat CRC mice models. We firstly reported the molecular mechanisms involved in the inhibition of CRC by I-125, mainly showing that a suitable dosage of I-125 can increase the expression of p53, which inhibits the expression of VEGF and causes lower MVD, leading to the cell apoptosis. The findings also indicated that MVD and VEGF were reliable combined predictors of prognosis in CRC. On the other hand, these findings support the hypothesis that VEGF is an important angiogenic factor in primary and metastatic human CRC. VEGF expression and vessel counts might aid in predicting patients at risk for metastasis from CRC, which is consistent with previous reports [37,38].

Regarding the tumor apoptosis caused by I-125 treatment, one important issue remains uncertain, namely that Figure 2D2, D3 is not completely clear and thus apoptosis may be confounded with mitotic death and pre-micronuclei formation. However, apoptosis can be evaluated by peroxidase-TUNEL (brown) counterstained with hematoxylin (blue) [39]. Thus, we still thought I-125 treatment caused the apoptosis of CRC but not mitotic death and pre-micronuclei formation since the nuclei were a brown color.

Epidemiologic studies have consistently reported positive associations between the weight and CRC risk for adults [40-42]. Achieving optimum BMI levels and weight reduction in the population appears to offer the greatest health benefits and decrease the risk of CRC $[43,44]$. Herein, we found that the I-125 treatment resulted in mice weight loss, which was the main reason for I-125 controlling the development of CRC. Thus, the molecular mechanisms for I-125 inhibiting CRC were that I-125 treatment increases the expression of p53 and reduces the expression of VEGF, which leads to a decrease of MVD. All the parameters were closely related with the weights of the mice models. The information should be beneficial to improve the treatment of various cancers with iodine.

The efficacy of iodine in treating various cancers is obvious [45-47], but its adverse effects are also protruding $[48,49]$. Even though the risk of I-125 for persistent side effects is rather small, these data do emphasize the need to carefully select the patients for I- 125 treatment. The CRC patients who are thought to be at moderate to high risk for recurrence, should use the minimally effective dose of I-125 activity, in an attempt to maximize the potential benefit while minimizing the risk for adverse events. Here, we found that the effective inhibition dosage of I-125 ranged from 0.4 to $0.8 \mathrm{mCi}$. The results offer important information for subsequent clinical trials and will be beneficial to utilize the iodine therapy techniques effectively and safely. Considering the side effects of I-125, controlled trials with a larger sample size and longer follow-up are recommended in the future.

\section{Conclusions}

In summary, we established animal models of CRC via the injection of HCT-8 cells into nude mice. Subsequently, the I-125 granules were implanted into the tumor of the 
animal model at different dosages. PCNA and TUNEL were used to detect apoptosis of the tumor cells. I-125 protests against CRC via increasing the protein level of p53 and decreasing the level of VEGF, which leads to the decrease of MVD in CRC. An effective inhibition dosage of I-125 ranged from 0.4 to $0.8 \mathrm{mCi}$.

\section{Abbreviations}

CRC: Colorectal cancer; I-125: lodine-125; MVD: Microvessel density; PCNA: Proliferating cell nuclear antigen; TUNEL: Terminal transferase dUTP nick end labeling; VEGF: Vascular endothelial growth factor.

\section{Competing interests}

The authors declare that they have no competing interests.

\section{Authors' contributions}

LB and ZL played equally important roles in the development of the experimental protocol. L-KY, S-QM, and M-ZH interpreted the results. The corresponding author, YY, was responsible for the tasks of co-ordination arrangements. All authors read and approved the final manuscript.

\section{Acknowledgments}

The study was supported by the Foundation of Applied Basic Research Program, Yunnan Province, China (No.2010CZ219; 2010CZ221; 2011FB150).

Received: 7 February 2014 Accepted: 4 July 2014

Published: 17 July 2014

\section{References}

1. Ferlay J, Shin HR, Bray F, Forman D, Mathers C, Parkin DM: Estimates of worldwide burden of cancer in 2008. Int J Cancer 2010, 127:2893-2917.

2. Zhang H, Li X, Ding J, Xu H, Dai X, Hou Z, Zhang K, Sun K, Sun W: Delivery of ursolic acid (UA) in polymeric nanoparticles effectively promotes the apoptosis of gastric cancer cells through enhanced inhibition of cyclooxygenase 2 (COX-2). Int J Pharm 2013, 441:261-268.

3. Morris EJ, Taylor EF, Thomas JD, Quirke P, Finan PJ, Coleman MP, Rachet B, Forman D: Thirty-day postoperative mortality after colorectal cancer surgery in England. Gut 2011, 60:806-813.

4. Glabbeke MV, Verweij J, Casali PG, Simes J, Cesne AL, Reichardt P, Issels R, Judson IR, van Oosterom AT, Blay J-Y: Predicting toxicities for patients with advanced gastrointestinal stromal tumours treated with imatinib: a study of the European Organisation for Research and Treatment of Cancer, the Italian Sarcoma Group, and the Australasian Gastro-Intestinal Trials Group (EORTC-ISG-AGITG). Eur J Cancer 2006, 42:2277-2285.

5. Ni RH, Wang G, Zhang ZM, Ma JG: lodine-125 seed implantation in the treatment of sacrococcygeal chordoma: a case report. Cell Biochem Biophys 2012, 64:107-113.

6. Buckstein M, Carpenter TJ, Stone NN, Stock RG: Long-term outcomes and toxicity in patients treated with brachytherapy for prostate adenocarcinoma younger than 60 years of age at treatment with minimum 10 years of follow-up. Urology 2013, 81:364-369.

7. Basha G, Penninckx F, Mebis J, Filez L, Geboes K, Yap P: Local and systemic effects of intraoperative whole-colon washout with 5 per cent povidone-iodine. Br J Surg 1999, 86:219-226.

8. Percivale P, Bertoglio S, Meszaros P, Schenone F, Gipponi M, Moresco L, Cosso M, Badellino F: Radioimmunoguided surgery with different iodine-125 radiolabeled monoclonal antibodies in recurrent colorectal cancer. Semin Surg Oncol 1998, 15:231-234.

9. Liu R, Luo F, Zhang Z, Xu Y: lodine-125 seed implantation and deferred transurethral resection of the prostate for patients with lower urinary tract symptoms and localized prostate cancer. Clin Genitourin Cancer 2013, 11:251-255.

10. da Silva Franca CA, Vieira SL, Carvalho AC, Bernabe AJ, Penna AB: Localized prostate cancer with intermediate- or high-risk features treated with combined external beam radiotherapy and iodine-125 seed brachytherapy. Brachytherapy 2010, 9:307-312.

11. Chen JB, Li JL, He LH, Liu WQ, Yao F, Zeng JY, Zhang Y, Xu KQ, Niu LZ, Zuo JS, Xu KC: Radical treatment of stage IV pancreatic cancer by the combination of cryosurgery and iodine-125 seed implantation. World I Gastroenterol 2012, 18:7056-7062.
12. Liu XH, Chen GG, Vlantis AC, Tse GM, van Hasselt CA: lodine induces apoptosis via regulating MAPKs-related p53, p21, and Bcl-xL in thyroid cancer cells. Mol Cell Endocrinol 2010, 320:128-135.

13. Rosner H, Torremante P, Moller W, Gartner R: Antiproliferative/cytotoxic activity of molecular iodine and iodolactones in various human carcinoma cell lines. No interfering with EGF-signaling, but evidence for apoptosis. Exp Clin Endocrinol Diabetes 2010, 118:410-419.

14. Yokoyama A, Tanaka Y, Yokoyama T, Mizukami T, Matsui T, Maruyama K, Omori T: p53 protein accumulation, iodine-unstained lesions, and alcohol dehydrogenase-1B and aldehyde dehydrogenase-2 genotypes in Japanese alcoholic men with esophageal dysplasia. Cancer Lett 2011, 308:112-117.

15. Yang L, Zhou J, Ma Q, Wang C, Chen K, Meng W, Yu Y, Zhou Z, Sun X: Knockdown of PPAR delta gene promotes the growth of colon cancer and reduces the sensitivity to bevacizumab in nude mice model. PLOS One 2013, 8:e60715.

16. Thalheimer A, Illert B, Bueter M, Gattenlohner S, Stehle D, Gasser M, Thiede A, Waaga-Gasser AM, Meyer D: Feasibility and limits of an orthotopic human colon cancer model in nude mice. Comp Med 2006, 56:105-109.

17. Baricault L, Denariaz G, Houri JJ, Bouley C, Sapin C, Trugnan G: Use of HT-29, a cultured human colon cancer cell line, to study the effect of fermented milks on colon cancer cell growth and differentiation. Carcinogenesis 1995, 16:245-252.

18. Hui X, Chen H, Zhang S, Ma X, Wang X, Huang B: Antitumor activities of recombinant human interferon (IFN)-lambda1 in vitro and in xenograft models in vivo for colon cancer. Cancer Lett 2011, 311:141-151.

19. Shiao YH, Palli D, Caporaso NE, Alvord WG, Amorosi A, Nesi G, Saieva C, Masala G, Fraumeni JF Jr, Rice JM: Genetic and immunohistochemical analyses of p53 independently predict regional metastasis of gastric cancers. Cancer Epidemiol Biomarkers Prev 2000, 9:631-633.

20. Darzynkiewicz Z, Galkowski D, Zhao H: Analysis of apoptosis by cytometry using TUNEL assay. Methods 2008, 44:250-254.

21. Takahashi Y, Kitadai Y, Bucana CD, Cleary KR, Ellis LM: Expression of vascular endothelial growth factor and its receptor, KDR, correlates with vascularity, metastasis, and proliferation of human colon cancer. Cancer Res 1995, 55:3964-3968.

22. Nieto Y, Woods J, Nawaz F, Baron A, Jones RB, Shpall EJ, Nawaz S: Prognostic analysis of tumour angiogenesis, determined by microvessel density and expression of vascular endothelial growth factor, in high-risk primary breast cancer patients treated with high-dose chemotherapy. Br J Cancer 2007, 97:391-397.

23. Leon SP, Folkerth RD, Black PML: Microvessel density is a prognostic indicator for patients with astroglial brain tumors. Cancer 1996, 77:362-372.

24. Chong BE, Yan F, Lubman DM, Miller FR: Chromatofocusing nonporous reversed-phase high-performance liquid chromatography/electrospray ionization time-of-flight mass spectrometry of proteins from human breast cancer whole cell lysates: a novel two-dimensional liquid chromatography/mass spectrometry method. Rapid Commun Mass Spectrom 2001, 15:291-296.

25. Shimada H, Ochiai T, Nomura F: Titration of serum p53 antibodies in 1085 patients with various types of malignant tumors. Cancer 2003, 97:682-689.

26. Yamagata M, Shiratori Y, Dan Y, Shiina S, Takayama T, Makuuchi M, Omata M: Serum endostatin levels in patients with hepatocellular carcinoma. Ann Oncol 2000, 11:761-762.

27. Zhang $\mathrm{DQ}, \mathrm{Guo} \mathrm{Q}$, Zhu JH, Chen WC: Increase of cyclooxygenase-2 inhibition with celecoxib combined with 5-FU enhances tumor cell apoptosis and antitumor efficacy in a subcutaneous implantation tumor model of human colon cancer. World J Surg Oncol 2013, 11:16-23.

28. Mullany LK, Liu Z, Wong KK, Deneke V, Ren YA, Herron A, Richards JS: Tumor repressor protein 53 and steroid hormones provide a new paradigm for ovarian cancer metastases. Mol Endocrinol 2014, 28:127-137.

29. Jain RK, Duda DG, Clark JW, Loeffler JS: Lessons from phase III clinical trials on anti-VEGF therapy for cancer. Nat Clin Pract Oncol 2006, 3:24-40.

30. Niu L, Zhou L, Xu K, Mu F: Combination of cryosurgery and lodine-125 seeds brachytherapy for lung cancer. J Thorac Dis 2012, 4:504-507.

31. Jarusevicius L, Inciura A, Juozaityte E, Vaiciunas K, Vaitkus A, Sniureviciute M: Comparison of implant quality between loose and intra-operatively linked iodine-125 seeds in prostate cancer brachytherapy. J Radiat Res 2012, 53:439-446.

32. Chen K, Xia Y, Wang H, Xiao F, Xiang G, Shen F: Adjuvant iodine-125 Brachytherapy for hepatocellular carcinoma after complete hepatectomy: a randomized controlled trial. PLoS One 2013, 8:e57397. 
33. Fang Z, Yan Z, Luo J, Liu Q, Qu X, Zhang W, Liu L, Wu L, Wang J: Evaluation of endovascular placement of iodine-125 seed straund combined with transcatheter arterial chemoembolization for treating hepatocellular carcinoma with extensive portal vein tumor thrombus. Chin J Hepatol 2013, 21:146-149.

34. Huang Q, Chen J, Chen Q, Lai Q, Cai S, Luo K, Lin Z: Computed tomographic-guided iodine-125 interstitial implants for malignant thoracic tumors. Eur J Radiol 2013, 82:2061-2066.

35. Ishida M, Sugawara A, Matsushima M, Ohara R, Katayama M, Nakajima Y: Rectal injury during permanent seed implantation for prostate Brachytherapy. Jpn J Clin Oncol 2012, 42:1207-1210.

36. Stone NN, Gerber NK, Blacksburg S, Stone J, Stock RG: Factors influencing urinary symptoms 10 years after permanent prostate seed implantation. J Urol 2012, 187:117-123.

37. Takahashi Y, Bucana CD, Cleary KR, Ellis LM: p53, vessel count, and vascular endothelial growth factor expression in human colon cancer. Int $J$ Cancer 1998, 79:34-38.

38. Takahashi Y, Tucker SL, Kitadai Y, Koura AN, Bucana CD, Cleary KR, Ellis LM: Vessel counts and expression of vascular endothelial growth factor as prognostic factors in node-negative colon cancer. Arch Surg 1997, 132:541-546.

39. Bonnaud S, Niaudet C, Legoux F, Corre I, Delpon G, Saulquin X, Fuks Z, Gaugler M-H, Kolesnick R, Paris F: Sphingosine-1-phosphate activates the AKT pathway to protect small intestines from radiation-induced endothelial apoptosis. Cancer Res 2010, 70:9905-9915.

40. Bassett JK, Severi G, English DR, Baglietto L, Krishnan K, Hopper JL, Giles GG: Body size, weight change, and risk of colon cancer. Cancer Epidemiol Biomarkers Prev 2010, 19:2978-2986.

41. Laake I, Thune I, Selmer R, Tretli S, Slattery ML, Veierod MB: A prospective study of body mass index, weight change, and risk of cancer in the proximal and distal colon. Cancer Epidemiol Biomarkers Prev 2010, 19:1511-1522.

42. Meyerhardt JA, Niedzwiecki D, Hollis D, Saltz LB, Mayer RJ, Nelson H, Whittom R, Hantel A, Thomas J, Fuchs CS: Impact of body mass index and weight change after treatment on cancer recurrence and survival in patients with stage III colon cancer: findings from Cancer and Leukemia Group B 89803. J Clin Oncol 2008, 26:4109-4115.

43. de Vries E, Soerjomataram I, Lemmens VE, Coebergh JW, Barendregt JJ, Oenema A, Moller H, Brenner H, Renehan AG: Lifestyle changes and reduction of colon cancer incidence in Europe: a scenario study of physical activity promotion and weight reduction. Eur J Cancer 2010, 46:2605-2616

44. Baicus C, Caraiola S, Rimbas M, Patrascu R, Baicus A, Gsspi: Ferritin above $100 \mathrm{mcg} / \mathrm{L}$ could rule out colon cancer, but not gastric or rectal cancer in patients with involuntary weight loss. BMC Gastroenterol 2012, 12:86-92.

45. Kobayashi M, Wakabayashi H, Kojima H, Konishi T, Okuda K, Yoneyama H, Kayano D, Tobisaka M, Tsushima H, Onoguchi M: Prototype imaging protocols for monitoring the efficacy of iodine-131 ablation in differentiated thyroid cancer. Hell J Nucl Med 2013, 16:175-180.

46. Moon JA, Yoo CH, Kim MH, Lee SM, Oh YJ, Ryu YH, Lee YS, Chang HS, Park CS, Lee KE: Knowledge, self-efficacy, and perceived barriers on the low-iodine diet among thyroid cancer patients preparing for radioactive iodine therapy. Clin Nutr Res 2012, 1:13-22.

47. Reddi HV, Madde P, McDonough SJ, Trujillo MA, Morris JC 3rd, Myers RM, Peng KW, Russell SJ, Mclver B, Eberhardt NL: Preclinical efficacy of the oncolytic measles virus expressing the sodium iodide symporter in iodine non-avid anaplastic thyroid cancer: a novel therapeutic agent allowing noninvasive imaging and radioiodine therapy. Cancer Gene Ther 2012, 19:659-665.

48. Almeida JP, Sanabria AE, Lima EN, Kowalski LP: Late side effects of radioactive iodine on salivary gland function in patients with thyroid cancer. Head Neck 2011, 33:686-690.

49. Grewal RK, Larson SM, Pentlow CE, Pentlow KS, Gonen M, Qualey R, Natbony L, Tuttle RM: Salivary gland side effects commonly develop several weeks after initial radioactive iodine ablation. J Nucl Med 2009, 50:1605-1610.

doi:10.1186/1477-7819-12-222

Cite this article as: Ma et al: lodine-125 induces apoptosis via regulating p53, microvessel density, and vascular endothelial growth factor in colorectal cancer. World Journal of Surgical Oncology 2014 12:222.

\section{Submit your next manuscript to BioMed Central and take full advantage of:}

- Convenient online submission

- Thorough peer review

- No space constraints or color figure charges

- Immediate publication on acceptance

- Inclusion in PubMed, CAS, Scopus and Google Scholar

- Research which is freely available for redistribution 